\title{
Effect of the PSP-causing dinoflagellate, Alexandrium sp. on the initial feeding response of Crassostrea gigas
}

\author{
David Wildish ${ }^{(1)}$, Patrick Lassus ${ }^{(2 *)}$, Jennifer Martin ${ }^{(1)}$, \\ Alinne Saulnier ${ }^{(1)}$, Michèle Bardouil ${ }^{(2)}$ \\ (1) Fisheries and Oceans Canada, Binlogical Station, St. Andreus, NB EOG 2 XO Canada. \\ E-mail: wildish@sta.dfo.ca \\ (2) IFREMER, B.P. 21105, 44311 Nantes cedex 031, France.
}

Received July 9, 1997; accepted October 27, 1997.

\begin{abstract}
The effects of toxic and non-toxic strains of Alexandrium sp. on the initial feeding responses of the Pacific oyster Crassostrea gigas were determined by continuous monitoring of the clearance rate of individual oysters. This was determined fluorometrically by loss of fluorescence of live microalgae introduced as food. Feeding oysters with toxic or non-toxic $A$. tamarense and toxic $A$. fundyense resulted in stop/start clearance behaviour. In contrast, control oysters fed a reference microalga, Isochrysis sp., known to support their growth, did not exhibit this behavior. Pacific oysters acclimated to Isochrysis sp., fed mixtures of Alexandrium/ Isochrysis, showed further evidence of stop/start clearance. Exposure for periods up to 48 hours with non-toxic $A$. tamarense did not enhance clearance of either Alexandrium or Isochrysis. (C) Ifremer-Elsevier, Paris
\end{abstract}

Crassostrea gigas / feeding physiology / toxic microalgae / dinoflagellate / paralytic shellfish poisoning.

Rếsumé - Effet d'un dinoflagellé producteur de PSP, Alexandrium sp., sur la réponse alimentaire précoce de Crassostrea gigas. Les effets de souches toxiques et de souches non toxiques d'Alexandrium sp. sur la réponse alimentaire précoce de l'huître creuse, Crassostrea gigas, ont été déterminés grâce à un contrôle continu du taux de tiltration individuel des huîtres. Ce taux a été évalué par la perte de fluorescence, mesurée par spectrofluorimétrie de flux, des microalgues introduites comme nourriture. Qu'elles soient alimentées avec $A$. tamarense toxique ou non toxique, ou avec $A$. fundyense toxique, les huîtres ont montré dans tous les cas une activité de filtration du type "ouverture/fermeture ". En revanche, les huîtres témoins nourries avec une algue de référence, Isochrysis sp., connue par ailleurs pour améliorer leur croissance, ne montraient pas ce type d'activité. Les huîtres creuses préacclimatées à une alimentation à base de Isochrysis $\mathrm{sp}$. et nourries avec différents mélanges Alexandrium/Isochrysis, ont également montré une filtration de type ouverture/fermeture. Des expositions de 48 heures au régime constitué d'A. tamarense non toxique n'ont pas amélioré la filtration, que ce soit avec Alexandrium ou Isochrysis. (C) Ifremer-Elsevier, Paris

Crassostrea gigas / physiologie alimentaire / microalgues toxiques / dinoflagellés / paralytic shellfish poisoning

${ }^{(*)}$ Corresponding author (e-mail: Patrick.Lassus@ifremer.fr) 


\section{INTRODUCTION}

The importance of toxic microalgae in relation to bivalves has implications for the marketing of either cultured or commercially dredged shellfish. This is because the presence of toxins from microalgae, such as the dinoflagellate Alexandrium sp., in the gut or tissues of bivalves can cause significant human health problems following ingestion. Many strains of Alexandrium can produce potent neurotoxins which, when ingested in sufficient amounts by vertebrates, result in paralytic shellfish poisoning (PSP). In humans, the sodium channel blocking action of this toxin can result in death, caused by interfering with the nervous system control of respiratory movements $[14,10]$. Chemically, the neurotoxin consists of a complex mixture of derivatives of saxitoxin and gonyautoxin in proportions which are strain-specific [1].

A growing body of work suggests that some commercially important bivalves can avoid ingesting toxic microalgae such as Alexandrium sp. One such bivalve is the northern quahaug, Mercenaria mercenaria, which retracts its siphon and closes its valves in the presence of Alexandrium sp. [15]. Other bivalves, e.g. some mussels and scallops, do not close their valves or select against toxic Alexandrium sp. [16, 6]. Speciesspecific feeding responses for a range of juvenile bivalves (although Crassostrea gigas was not included) occur when a particular strain of toxic A. tamarense is present [13].

Previous studies of the effect of toxic and non-toxic strains of Alexandrium sp. on feeding by $C$. gigas have been undertaken by Dupuy and Sparks [7] who studied the effect of toxic Alexandrium catenella on feeding and toxin uptake in bioassay experiments. In these tests, oysters curtailed or stopped feeding and undertook vigorous valve clapping behavior. Cell densities of $20-120 \times 10^{3}$ cells $\cdot \mathrm{L}^{-1}$ of A. catenella were reported by Dupuy and Sparks [7] to cause complete cessation of feeding. In the feeding bioassays of $C$. gigas undertaken by Bardouil et al. [2], a flow-through system was used with oysters acclimated to a unialgal diet of the diatom Thalassiosira weissflogii. The oysters were subsequently exposed to unialgal cultures of A. tamarense (the same toxic and non-toxic strain used herein), toxic A. minutum and non-toxic Scrippsiella trochoidea. In general, this work confirmed Dupuy and Sparks [7] results that toxic Alexandrium sp. inhibits feeding and enhances valve clapping. During the laboratory experiments of Bardouil et al. [2], at unknown but probably low flow speeds, oyster clearance rates decreased in the order: $S$. trochoidea $>A$. minutum $>$ non-toxic $A$. tamarense $>$ toxic $A$. tamarense. Bardouil et al. [3] also showed that mixed cultures of A. tamarense $+T$. weissflogii (1:9 and $1: 1$ concentrations by cell density) reduced oyster clearance rates compared to the reference (T. weissflogii) diet. This bioassay did not allow continuous monitoring of filtration rates as samples were only taken at the beginning and end of the experiment.

Lassus et al. [12], in a parallel study to the present one, used the same species of Alexandrium sp. and C. gigas, but emphasized the post-ingestive stages of the feeding process. For the present study, we followed Wildish and Kristmanson's [20] description of the feeding stages common to benthic suspension feeding animals. In this presentation, we are concerned only with the first two stages of bivalve feeding physiology, which we refer to as the initial feeding stages, as determined in a filtration bioassay.

Our objective was to determine how toxic and nontoxic strains of $A$. tamarense and $A$. fundyense affect the initial feeding responses of $C$. gigas at realistic flow speeds throughout the bioassay, lasting up to $150 \mathrm{~min}$. Experiments were devised to compare filtration rates in oysters fed toxic and non-toxic strains of Alexandrium sp., with those fed a reference microalga, Isochrysis $\mathrm{sp}$., to determine whether a preference could be demonstrated.

\section{MATERIALS AND METHODS}

The experiments of Bougrier et al. [5] which took place in small, individual flow-through units, where the velocities near the oyster were unknown, although according to the volumetric flows used, were likely to be in the optimal range for this species. Consequently, we have used the numerical predictions for clearance rate based on oyster dry weight and temperature given by Bougrier et al. [5] to compare with the data obtained during our work.

To facilitate this work we have utilized the empirically derived, non-linear equation derived by Bougrier et al. [5] for $C$. gigas that relates clearance rate $(\mathrm{R}, \mathrm{L}$. $\mathrm{h}^{-1}$ ) to temperature $\left(\mathrm{T},{ }^{\circ} \mathrm{C}\right)$ and dry tissue weight (D, g), thus:

$$
\mathrm{R}=\left[4.825-\left(0.013 \times(\mathrm{T}-18.954)^{2}\right)\right] \times \mathrm{D}^{0.439}
$$

One hundred oysters were obtained from a commercial grower (Innovative Aquaculture Products, Vancouver, BC) in May 1994 and again in October 1995. The oysters had not been conditioned for spawning and were not in breeding condition. Sizes ranged from $6-10 \mathrm{~cm}$ in valve height and $1-5 \mathrm{~g}$ dry tissue weight, on use in the feeding experiments. They were shipped by air in seaweed and ice and, immediately on receipt in St. Andrews, were placed in a $150 \mathrm{~L}$ flowthrough holding tank in small baskets suspended in the tank seawater. Undoubtedly, this treatment resulted in temperature shocks, so the oysters were acclimated in the holding tank for a minimum period of 6 weeks. The flow from the holding tank was collected for quarantine purposes in a large round tank containing $2 \%$ sodium hypochlorite which was emptied once or twice per day. Seawater supplied to the holding tank was the Biological Station seawater supply-sand-filtered with 
salinity of $\sim 30$ at close to ambient seawater temperature. Oysters were fed once daily a mixture of from 2 to $4 \mathrm{~L}$ Isochrysis $\mathrm{sp}$. in $\log$ /stationary phase at $\sim 10^{6}$ cells $\cdot \mathrm{L}^{-1}$.

Cultures of Alexandrium sp. and Isochrysis sp., strain T-ISO (Tahitian), were grown in enriched, filtered seawater medium " $f$ "/2 [8]. This medium was made using seawater from the Bay of Fundy at a salinity of $\sim 30$. Cultures were maintained at $14{ }^{\circ} \mathrm{C}$ and at a light intensity of $40 \mu \mathrm{E} \cdot \mathrm{m}^{-2} \cdot \mathrm{s}^{-1}$ on a 14-hour daily light period. Characteristics of the microalgae tested with oysters are shown in table 1 . The two toxic strains of Alexandrium sp. used contained the following saxitoxin equivalent levels: MOG 835-7 $200 \mathrm{ng}$ equivalents per $10^{6}$ cells, and GONY 7-13000 ng equivalents per $10^{6}$ cells, as determined by reverse phase, ion-pairing HPLC [17].

Clearance rate was determined for each oyster in a $205 \mathrm{~L}$ recirculating, temperature-controlled flume as described in Wildish and Saulnier [21], except that the acrylic cylinder of $1 \mathrm{~cm}$ diameter placed sideways at the entrance to the working section to create an $8 \mathrm{~cm}$ deep benthic boundary layer was not used in the present experiments. Thus, the boundary layer in the working section was $<2 \mathrm{~cm}$ high. Two Nixon Stream Flo probes measured flow speed $\left(\mathrm{U}\right.$, as $\left.\mathrm{cm} \cdot \mathrm{s}^{-1}\right)$ throughout the experiments: the first was positioned just in front of the oyster, and level with the inhalant opening, and the second at mid-depth and mid-width of the flume working section. Because both probes gave essentially similar results, flow speed averages shown are for the probe placed in front of the oyster. The temperature probe was positioned at mid-depth and the intake of the light-shielded, plastic tube (internal diameter $1.5 \mathrm{~cm}$ ) flow fluorometer Model 10-AU005 Turner Designs, Sunnyvale, CA, USA, was positioned at the upstream end of the working scetion. A submersible pump (Little Giant Co., Oklahoma City, USA) delivered seawater to the fluorometer at $\sim 9.61 \cdot \mathrm{min}^{-1}$. This flow rate was isokinetic at $-91 \mathrm{~cm} \cdot \mathrm{s}^{-1}$ free stream velocity in the flume working section. The fluorometer outflow was returned to a point just above the flume propeller. Velocity, temperature and fluorometer readings were recorded at halfminute intervals throughout the experiment by connecting their outputs to a data logger: PCA-48 channel from Diana Chart Inc., NJ, USA, linked to a personal computer. Mean and standard errors of the first two variables were computed for the duration of the experimental period.
A calculated volume of Isochrysis sp. stock culture of known concentration was added to sand-filtered seawater to achieve the desired cell concentration. Cells were counted microscopically with a haemocytometer and related to direct fluorometric determination of chlorophyll $a$ in living cells. Alexandrium sp. were counted with a Palmer Maloney chamber and also related to chlorophyll $a$ in living cells. We also measured the dry weight (in a desiccator) of the cultures by filtering known volumes and cell concentrations on Millipore matched weight filters of nominal porosity $0.45 \mu \mathrm{m}$.

A 10-day acclimation period for temperature and change to feeding with a mixed culture consisting of Isochrysis galbana, strain T-ISO, and Chaetoceros calcitrans was used for each experiment.

\subsection{Experimental protocol}

The design of each experiment was the same, with the flume operated at the required flow with added microalgae, without an oyster, to obtain a blank estimate of the rate of cell settlement during the first $60 \mathrm{~min}$. Subsequently, an oyster was placed in the flume and continuous-flow fluorometer, velocity and temperature records were made as described above for periods ranging from an additional 60-150 $\mathrm{min}$.

It has been shown in other bivalves, c.g. in the scallop, Placopecten magellanicus [21], that the filtration rate is unimodally related to seston concentration or velocity. Thus, in preliminary experiments 1 and 2, we sought to determine the optimum filtration rates for Pacific oysters for each variable. Since the aim of these experiments was not to prove that velocity or seston concentration influenced clearance rates, the various treatment levels were not replicated.

In preliminary studies (experiment 1), we examined the effect of non-toxic Alexandrium tamarense cell density on seston uptake rates. During further preliminary studies (experiment 2A), a constant microalgal density of $75 \times 10^{3}$ cells $\cdot \mathrm{L}^{-1}$ was used to investigate the effect of a linited range of flow speeds: $7-29 \mathrm{~cm} \cdot \mathrm{s}^{-1}$ on filtration rate $(\mathrm{R})$; and in experiment $2 \mathrm{~B}$, oysters fed $5.5 \times 10^{6}$ cells $\cdot \mathrm{L}^{-1}$ of Isochrysis over a flow speed range of $8-25 \mathrm{~cm} \cdot \mathrm{s}^{-1}$ were used to determine its effect on $\mathrm{R}$. For the main experiments comparing toxic and non-toxic Alexandrium sp., with a reference microalga, we used optimum flow conditions.

In experiment $3 \mathrm{~A}$, we compared the filtration rate of toxic and non-toxic Alexandrium sp. to that of Iso-

Table I. Dry weight estimation of Alexandrium sp. and Isochrysis sp. used in oyster feeding experiments (ng.cell ${ }^{-1}$ ).

\begin{tabular}{llcccc}
\hline Species & $\begin{array}{l}\text { Strain } \\
\text { (and source) }\end{array}$ & $\begin{array}{c}\text { Culture age } \\
\left(\mathrm{d}^{-1}\right)\end{array}$ & $\begin{array}{c}\text { Cells } \\
\left(\times 10^{3} \cdot \mathrm{L}^{-1}\right)\end{array}$ & \multicolumn{2}{c}{ Dry weight $\left(10^{-9} /\right.$ cell) } \\
\cline { 4 - 6 } & & 9 & 3.84 & 3.54 & 1994 \\
\hline A. tamarense & CCMP 115 (English Channel) & 15 & 5.55 & 8.26 & 5.09 \\
A. tamarense & MOG 835 (Japan Sea) & 10 & 3.80 & 5.53 & 4.94 \\
A. fundyense & GONY 7 (Bay of Fundy) & 2 & $1200 \times 10^{3}$ & 0.02 \\
Isochrysis sp. & T-ISO (Tahitian) & & \\
\hline
\end{tabular}

Aquat. Living Resour. 11 (1) (1998) 


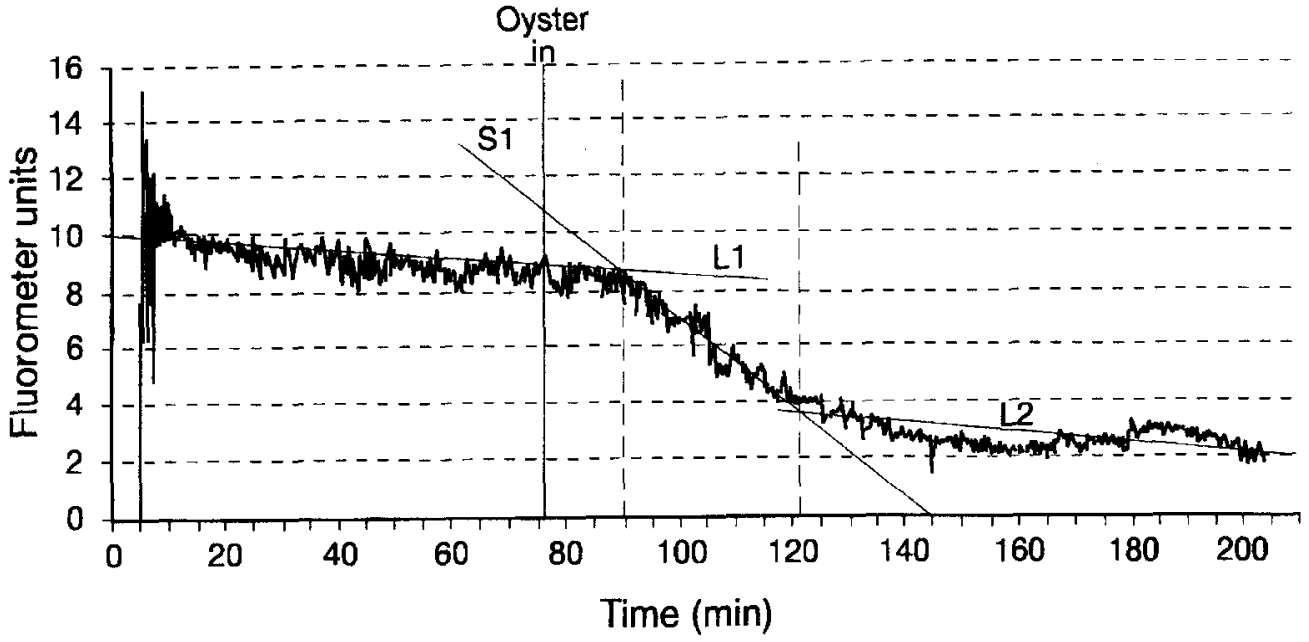

Figure 1. Computer-generated output from the direct measurement of chlorophyll $a$ in live Alexandrium tamarense cells $\left(50 \times 10^{3}\right.$ cells $\left.\mathrm{L}^{-1}\right)$ in the flume. S1, oyster filtration and settling loss rate; $\mathrm{L} 1$ and $\mathrm{L} 2$, settling losses only.

chrysis sp. with oysters acclimated to the latter species. In experiment $3 B$, we tested prior exposure for $12-48 \mathrm{~h}$ with non-toxic $A$. tamarense in an attempt to induce feeding responses. Finally, in experiment $3 \mathrm{C}$, we tested oysters acclimated to Isochrysis sp. to see whether mixed cultures of Alexandrium and Isochrysis could induce feeding.

\subsection{Data analysis}

For each experiment, computer-generated output from the fluorometer was obtained. The construction lines used in analysing this record are shown in figure 1 . In this example, the oyster began filtering after $14 \mathrm{~min}$ in the flume at a rate, S1, faster than settling losses, L1, for $33 \mathrm{~min}$ before slowing, over a period of $\sim 15 \mathrm{~min}$. The slowing period was ignored, and for the last $62 \mathrm{~min}$ of the experiment, the oyster was not considered to be filtering, as L1 and L2 were equal in slope and little chlorophyll $a$ remained in the flume. Each fluorometer record was scrutinized in this way to determine how many times active feeding was initiated and stopped during the $60-150 \mathrm{~min}$ experimental period. The percentage of time feeding was also determined for each experimental period, designated as $1,2, \ldots \mathrm{n}$, that the oyster was feeding. Individual clearance rates for $\mathrm{S} 1, \mathrm{~S} 2, \ldots \mathrm{Sn}$ were then determined as below.

Because in some cases $\mathrm{C} 2<0.9 \mathrm{Cl}$, it was necessary [20] to use Coughlan's formula to estimate the raw clearance rate, $R_{r}$, of individual oysters. Thus,

$$
\mathrm{R}_{\mathrm{r}}=\mathrm{Vt} / 60 \ln (\mathrm{C} 1 / \mathrm{C} 2)
$$

where $\mathrm{C} 1$ is the initial cell density as number of cells. $\mathrm{L}^{-1}$ and $\mathrm{C} 2$ is the final cell density in the same units, $\mathrm{V}$ is the flume volume in litres and $t$ is experimental period in minutes. Since (1) includes both clearance and settlement losses, the corrected clearance rate, $\mathrm{R}$, due only to oyster uptake, in $1 . \mathrm{h}^{-1}$ per oyster, is:

$$
\mathrm{R}=\mathrm{R}_{\mathrm{r}} \times\left[\mathrm{Vt} / 60 \ln (\mathrm{C} 1 / \mathrm{C} 2)_{\text {blank }}\right]
$$

$(\mathrm{C} 1 / \mathrm{C} 2)_{\text {blank }}$ is the settling rate in cells per $\mathrm{L}^{-1}$ determined in the first hour of the experiment, with no oyster present. For the calculation of $\mathrm{Cl}$ and $\mathrm{C} 2$ in all equations, it was necessary to use the actual initial (C1) and final (C2) cell densities. This was achieved for each individual oyster experiment by measuring a known cell concentration of Alexandrium sp. with the fluorometer so that at least three concentrations in the range of interest were measured. In all cases, straightline regression lines (figure 2 ) adequately represented the relationship:

$$
\text { Cell density }=\mathrm{a}+\mathrm{b} \text { fluorometer units }
$$

with $\mathrm{r}^{2} \geq 0.95$. In some cases, it was possible to group the data from individual experiments.

Statistical tests included comparisons between observed and predicted $R$ values based on the $t$ test for independent samples. For feeding/non-feeding results, we used the $\chi^{2}$ test.

\section{RESULTS}

Cell densities with each strain of Alexandrium sp., up to $400 \times 10^{3} \cdot \mathrm{I}^{-1}$, gave a linear fluorometric response (figure 2) supporting the view that quenching effects in this range were absent.

Microalgal settling rate was one factor affecting the sensitivity limit of the fluorometric method to detect Alexandrium $\mathrm{sp}$. The settling rate was density-dependent, and at $<100 \times 10^{3}$ cells $\cdot \mathrm{L}^{-1}$, the rate was less than at $>100 \times 10^{3}$ cells $\cdot L^{-1}$. 


\subsection{Experiment 1}

The effect of microalgal density on the initial feeding responses of $C$. gigas is shown in table II. Of the 6 oysters tested during this experiment, 2 individuals

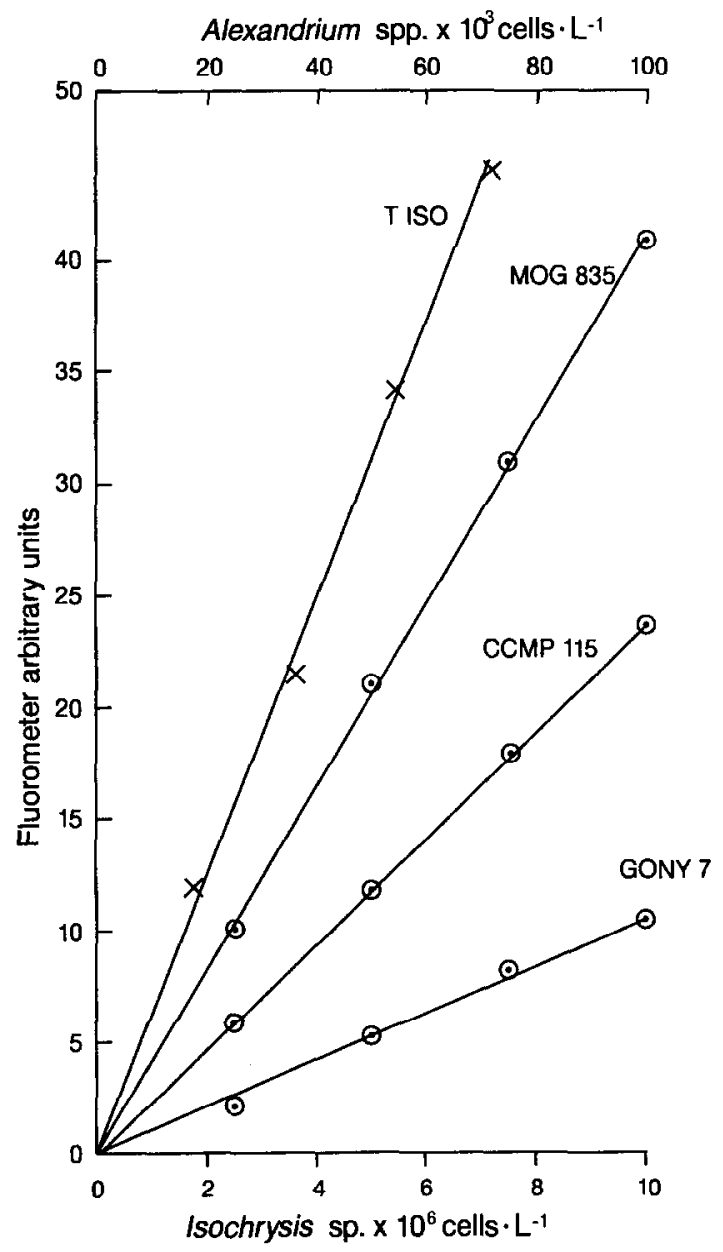

Figure 2. Calibration curve for Alexandrium sp. and Isochrysis sp. as cell density, $x$ axis, in cells $\cdot \mathrm{L}^{-1}$ against raw fluorescence, arbitrary units, $y$ axis. Strain indicated on each curve. did not open or feed. The other oysters opened and closed their valves 1-3 times during the experiment, as indicated by a rapid shift of the fluorometer slope (figure 1). The start/stop feeding observed in this way proved to be a characteristic response of oysters in experiments involving Alexandrium sp. During the experiment with oyster \#1, most of the A. tamarense cells had either been deposited on the flume walls or filtered by the oyster within 48 min (figure 1) and this can explain why it stopped feeding. To calculate the observed value of $\mathrm{R}$ in table II, we multiplied the $\mathrm{R}$ calculated for $S_{1}, S_{2} \ldots S_{n}$ by the time that each feeding persisted, then divided by the exposure period. Most of the observed values in table II were less than those predicted by Bougrier et al. [5]. There is the suggestion of a concentration effect in the results (table II) with $>50$ cells $\cdot \mathrm{L}^{-1} \times 10^{3}$ being required to have an effect on $\mathrm{R}$.

\subsection{Experiment 2}

The effect of flume speed on $\mathrm{R}$ in otherwise similar conditions to experiment 1 is shown in table III. A. tamarense losses due to settlement of cells on flume walls were not affected by flume speed, and averaged an equivalent $\mathrm{R}$ of $1.5 \mathrm{~L} \cdot \mathrm{h}^{-1}$. Two oysters during experiment 2A did not feed at the two highest flows tested. Of the active oysters, \#3 initiated and stopped feeding four times and the others only once (table 3). An unrealistically high $\mathrm{R}$ value for oyster \#1 during S1 may be linked to the difficulty of determining when the oyster actually started and stopped feeding. For tables II and $I I I$, the mean R values, calculated on the basis of the whole exposure period, were significantly less than the predicted ones from the Bougrier model at the same temperature and oyster weight. The means were 3.35 versus $7.59 \mathrm{~L} \cdot \mathrm{h}^{-1}$ (observed/predicted) with student $t=2.80, \mathrm{df}=7, P<0.05$.

In experiment $2 \mathrm{~B}$ (table $\mathrm{IV}$ ), oysters were provided with a reference diet consisting of $5.5 \times 10^{6}$ cells $\cdot \mathrm{L}^{-1}$ of Isochrysis sp. During this test and in all others involving this microalga, Pacific oysters never initiated and then stopped feeding, as was the case with Alexandrium sp. Nevertheless, in 5 cases of 12 , the oysters did

Table II. Experiment 1: Effect of dinoflagellate density on the initial feeding response of Crassostrea gigas fed Alexandrium tamarense, strain CCMP 115. Oysters were in the flume for $120-131 \mathrm{~min}$, temperature $10.5 \pm 0.18^{\circ} \mathrm{C}$ and $\mathrm{U}=10.9 \pm 0.15 \mathrm{~cm} \cdot \mathrm{s}^{-1}$

\begin{tabular}{|c|c|c|c|c|c|c|c|c|}
\hline \multicolumn{2}{|c|}{ Oyster } & \multirow[t]{2}{*}{$\begin{array}{l}\text { Initial cell density } \\
\left(10^{3} \text { cells } \cdot \mathrm{L}^{-1}\right)\end{array}$} & \multirow{2}{*}{$\begin{array}{l}\text { No. times } \\
\text { feeding } \\
\text { initiated }\end{array}$} & \multicolumn{3}{|c|}{$\begin{array}{c}\text { Time (min) } \\
\text { feeding persists }\end{array}$} & \multicolumn{2}{|c|}{$\begin{array}{c}\text { Clearance rate R } \\
\left(\mathrm{L} \cdot \mathrm{h}^{-1}\right)\end{array}$} \\
\hline$\#$ & $\begin{array}{l}\text { Dry weight } \\
\text { (g) }\end{array}$ & & & S1 & $\mathrm{S} 2$ & $\mathrm{~S} 3$ & Observed & Predicted \\
\hline 1 & 3.770 & 50 & 1 & 48 & - & - & 12.6 & 7.5 \\
\hline 2 & 2.548 & 75 & 3 & 17 & 50 & 14 & 2.0 & 6.3 \\
\hline 3 & 4.597 & 100 & 2 & 88 & 9 & - & 1.3 & 8.2 \\
\hline 4 & 4.718 & 100 & 1 & 37 & - & - & 0.4 & 8.3 \\
\hline 5 & 4.566 & 200 & 0 & - & - & - & - & 8.2 \\
\hline 6 & 2.006 & 400 & 0 & - & - & - & - & 5.9 \\
\hline
\end{tabular}

Aquat. Living Resour. 11 (1) (1998) 
not begin feeding when offered the reference diet (table IV). Of the 7 remaining oysters that did initiate feeding, the observed mean $\mathrm{R}$ was not significantly different from the predicted value of Bougrier et al. [5]: 6.59 vs. $6.91 \mathrm{~L} \cdot \mathrm{h}^{-1}$, student $t=-0.261, \mathrm{df}=6$, $P=0.80$. For the velocities tested in table $I V$, there was no obvious effect of this variable on $\mathrm{R}$, as there seemed to be with non-toxic Alexandrium sp. (table III).

\subsection{Experiment 3}

The results of experiment $3 \mathrm{~A}$ (table $V$ ) clearly show that oysters select Isochrysis sp. over Alexandrium spp. as food. When offered a preferred reference diet of 1 sochrysis $\mathrm{sp}$. in experiment 3 , most oysters were filtering suboptimally when compared with the Bougrier et al. [5] predictive model. Thus the observed mean $\mathrm{R}=2.667 \mathrm{~L} \cdot \mathrm{h}^{-1}$ was significantly less than the predicted mean $\mathrm{R}=6.589 \mathrm{~L} \cdot \mathrm{h}^{-1}$ derived from the model, student $t=-4.027, \mathrm{df}=9, P<0.01$. We conclude that the oyster subjects may have been showing signs of stress due to unknown factors in the bioassay conditions, or to prior treatment. For the oysters offered Alexandrium sp., none of those tested began to feed during the $150 \mathrm{~min}$ exposure period of this experiment.

In experiment $3 \mathrm{~B}$, we exposed 18 oysters to a nontoxic strain of $A$. tamarense for periods varying from 12 to $48 \mathrm{~h}$ (table VI). These oysters all had a previous history in our culture conditions of consuming Isochrysis sp. The acclimation cell density of $A$. tamarense, strain CCMP 115 , was $1.185 \times 10^{4}$ cells $\cdot \mathrm{L}^{-1}$. The results shown in table VI suggest that the prior exposure treatment did not change the oysters' feeding responses.

In experiment $3 \mathrm{C}$, we determined whether mixed cultures of Isochrysis sp. and Alexandrium sp. could initiate feeding in $C$. gigas. The oysters used in this experiment had a previous feeding history of exposure to Isochrysis sp. during the holding period. The cell densitics of cach microalga used during this experiment were adjusted so that each was of equal dry weight. The results are summarized in table VII and show that six out of eight oysters did initiate feeding during a $150 \mathrm{~min}$ experimental exposure period to the mixed microalgae. Half of the six oysters also closed before the end of the exposure period. These results are consistent with the view that mixed cultures containing at least one preferred species encourage feeding initiation, but that the presence of Alexandrium sp. causes valve closing and, hence, start/stop feeding. For oysters feeding on a mixed microalgae containing strain CCMP 115, mean $\mathrm{R}$ was not significantly different for the experimental group: 8.400 vs. the predicted value, $6.167 \mathrm{~L} \cdot \mathrm{h}^{-1}$, student $t=3.198, \mathrm{df}=2$, NS $P>0.05$. For oysters feeding on mixed microalgae containing

Table III. Experiment 2A: Effect of velocity on the initial feeding responses of Crassostrea gigas fed Alexandrium tamarense, strain CCMP 115 at a cell density of $75 \times 10^{3}$ cells $\cdot \mathrm{L}^{-1}$. Oysters were in the flume for $131-137 \mathrm{~min}$, temperature $11.9 \pm 0.16{ }^{\circ} \mathrm{C}$. Clearance rate: $\mathrm{R}$.

\begin{tabular}{|c|c|c|c|c|c|c|c|c|c|c|}
\hline \multicolumn{2}{|c|}{ Oyster } & \multicolumn{2}{|c|}{$\mathrm{U}, \mathrm{cm} \cdot \mathrm{s}^{-1}$} & \multirow{2}{*}{$\begin{array}{l}\text { Percent of } \\
\text { time feeding }\end{array}$} & \multicolumn{4}{|c|}{$\mathrm{R}, 1 . \mathrm{h}^{-1}$ oyster (time feeding, $\min$ ) } & \multicolumn{2}{|c|}{$\mathrm{R}, 1 . \mathrm{h}^{-1}$ oyster (overall) } \\
\hline$\#$ & Dry wt $(\mathrm{g})$ & Mean & \pm S.D. & & S1 & S2 & S3 & S4 & Observed & Predicted \\
\hline 1 & 4.650 & 7.1 & 0.71 & 12 & $54(17)$ & - & - & - & 6.8 & 8.2 \\
\hline 2 & 4.718 & 10.6 & 0.95 & 33 & $3.6(44)$ & - & - & _ & 1.2 & 8.3 \\
\hline 3 & 2.548 & 15.0 & 0.92 & 65 & $2.1(58)$ & $5.6(8)$ & $7.3(9)$ & $10.6(9)$ & 0.6 & 6.3 \\
\hline 4 & 3.857 & 19.1 & 0.68 & 62 & $3.2(82)$ & - & - & - & 1.9 & 7.6 \\
\hline 5 & 4.680 & 24.4 & 1.16 & 0 & & & - & & -- & 8.2 \\
\hline 6 & 1.735 & 28.9 & 2.09 & 0 & - & - & - & - & - & 5.6 \\
\hline
\end{tabular}

Table IV. Experiment 2B: Effect of velocity on the initial feeding responses of Crassostrea gigas fed Isochrysis sp. at $5.5 \times 10^{6}$ cells $\cdot \mathrm{L}^{-1}$ and temperature of $15.3 \pm 0.12{ }^{\circ} \mathrm{C}$. Clearance rate: $\mathrm{R}$.

\begin{tabular}{|c|c|c|c|c|c|c|}
\hline \multicolumn{2}{|c|}{ Oyster } & \multicolumn{2}{|c|}{$\mathrm{U}, \mathrm{cm} \cdot \mathrm{s}^{-1}$} & \multirow{2}{*}{$\begin{array}{l}\text { Time delay ( } \mathrm{min}) \\
\text { to feeding }\end{array}$} & \multicolumn{2}{|c|}{ R L $\cdot h^{-1}$ oyster } \\
\hline$\#$ & Dry wt. (g) & Mean & \pm S.D. & & Observed & Predicted \\
\hline 1 & 3.295 & 8.2 & 2.42 & $>150$ & - & - \\
\hline 2 & 1.984 & 9.5 & 1.14 & $>150$ & - & - \\
\hline 3 & 1.581 & 10.2 & 1.47 & $>150$ & - & - \\
\hline 4 & 1.686 & 10.8 & 0.23 & 16 & 6.7 & 5.8 \\
\hline 5 & 2.255 & 16.5 & 1.24 & 14 & 6.1 & 6.6 \\
\hline 6 & 3.988 & 16.8 & 0.41 & 25 & 12.4 & 8.5 \\
\hline 7 & 1.628 & 18.9 & 1.46 & $>150$ & - & - \\
\hline 8 & 2.823 & 19.8 & 0.55 & 12 & 4.2 & 7.3 \\
\hline 9 & 1.987 & 19.9 & 0.51 & $>150$ & - & - \\
\hline 10 & 2.475 & 20.3 & 0.70 & 13 & 0.8 & 6.9 \\
\hline 11 & 2.182 & 23.6 & 0.59 & 14 & 7.1 & 6.5 \\
\hline 12 & 2.378 & 24.3 & 0.58 & 25 & 8.8 & 6.8 \\
\hline
\end{tabular}


Table V. Experiment 3A: Comparison of initial feeding responses of Crassostrea gigas fed Isochrysis sp. at $5.5 \times 10^{6}$ cells $\cdot \mathrm{L}^{-1}$ vs. the same dry weight for Alexandrium sp. Environmental conditions, temperature $=15.1 \pm 0.1{ }^{\circ} \mathrm{C}$ and $\mathrm{U}=15.9 \pm 0.9 \mathrm{~cm} \cdot \mathrm{s}^{-1}$, for $\# 1-10$ and $15.2 \pm 0.1{ }^{\circ} \mathrm{C}$ and $\mathrm{U}=15.9 \pm$ $0.7 \mathrm{~cm} \cdot \mathrm{s}^{-1}$ for $\# 11-22$.

\begin{tabular}{|c|c|c|c|c|c|}
\hline \multicolumn{2}{|c|}{ Oyster } & \multirow[t]{2}{*}{ Strain } & \multirow{2}{*}{$\begin{array}{l}\text { Time delay } \\
\text { to feeding ( } \min \text { ) }\end{array}$} & \multicolumn{2}{|c|}{$\mathrm{R} L \cdot \mathrm{h}^{-1}$ oyster } \\
\hline$\#$ & Dry weight $(\mathrm{g})$ & & & Observed & Predicted \\
\hline \multicolumn{6}{|c|}{ Isochrysis $\mathrm{sp}$. } \\
\hline 1 & 2.009 & \multirow{10}{*}{ T-ISO } & 50 & 6.6 & 6.3 \\
\hline 2 & 0.974 & & 14 & 4.5 & 4.6 \\
\hline 3 & 2.513 & & $>150$ & 0.0 & 6.9 \\
\hline 4 & 2.269 & & 0 & 0.6 & 6.6 \\
\hline 5 & 2.009 & & 21 & 2.8 & 6.3 \\
\hline 6 & 0.974 & & 33 & 1.7 & 4.6 \\
\hline 7 & 3.298 & & 12 & 1.7 & 7.8 \\
\hline 8 & 3.542 & & 8 & 2.8 & 8.1 \\
\hline 9 & 5.531 & & 6 & 1.1 & 9.8 \\
\hline 10 & 1.321 & & 14 & 2.2 & 5.2 \\
\hline \multicolumn{6}{|c|}{ Alexandrium $\mathrm{sp}$. } \\
\hline 11 & 2.762 & \multirow{4}{*}{ CCMP 115} & $>150$ & 0 & 7.2 \\
\hline 12 & 3.546 & & $>150$ & 0 & 8.1 \\
\hline 13 & 2.396 & & $>150$ & 0 & 6.8 \\
\hline 14 & 1.214 & & $>150$ & 0 & 5.0 \\
\hline 15 & 2.762 & \multirow{4}{*}{ MOG 835} & $>150$ & 0 & 7.2 \\
\hline 16 & 2.679 & & $>150$ & 0 & 7.1 \\
\hline 17 & 4.514 & & $>150$ & 0 & 9.0 \\
\hline 18 & 3.876 & & $>150$ & 0 & 8.4 \\
\hline 19 & 2.842 & \multirow{4}{*}{ GONY 7} & $>150$ & 0 & 7.3 \\
\hline 20 & 2.878 & & $>150$ & 0 & 7.4 \\
\hline 21 & 2.396 & & $>150$ & 0 & 6.8 \\
\hline 22 & 3.546 & & $>150$ & 0 & 8.1 \\
\hline
\end{tabular}

Table VI. Experiment 3B: Initial feeding responses of Crassostrea gigas exposed to pre-feeding with Alexandrium tamarense - strain CCMP 115 at $1.185 \times 10^{4}$ cells $\mathrm{L}^{-1}$. Environmental conditions, tempcrature $=15.3 \pm 0.09$ and $\mathrm{U}=15.4 \pm 0.5 \mathrm{~cm} \cdot \mathrm{s}^{-1}$.

\begin{tabular}{|c|c|c|c|c|c|}
\hline \multicolumn{2}{|c|}{ Oyster } & \multirow{2}{*}{$\begin{array}{l}\text { Pre-feeding } \\
\text { time } \\
\text { (h) }\end{array}$} & \multicolumn{2}{|c|}{ Experimental conditions } & \multirow{2}{*}{$\begin{array}{l}\text { Time delay } \\
\text { to feeding } \\
\text { (min) }\end{array}$} \\
\hline$\#$ & $\begin{array}{l}\text { Dry weight } \\
(\mathrm{g})\end{array}$ & & Strain & $\begin{array}{l}\text { Cell density, } \\
10^{3} \text { cells } \cdot \mathbf{L}^{-1}\end{array}$ & \\
\hline 1 & 2.555 & 12 & CCMP 115 & 11.85 & $>150$ \\
\hline 2 & 3.027 & 12 & CCMP 115 & 11.85 & $>150$ \\
\hline 3 & 2.248 & 12 & MOG 835 & 6.0 & $>150$ \\
\hline 4 & 2.631 & 12 & MOG 835 & 6.0 & $>150$ \\
\hline 5 & 5.531 & 12 & GONY 7 & 6.83 & $>150$ \\
\hline 6 & 2.299 & 12 & GONY 7 & 6.83 & $>150$ \\
\hline 7 & 3.491 & 24 & MOG 835 & 3.41 & $>150$ \\
\hline 8 & 3.700 & 24 & MOG 835 & 3.41 & $>150$ \\
\hline 9 & 3.400 & 24 & GONY 7 & 5.61 & $>150$ \\
\hline 10 & 2.196 & 24 & GONY 7 & 5.61 & $>150$ \\
\hline 11 & 3.245 & 24 & CCMP 115 & 8.71 & $>150$ \\
\hline 12 & 4.259 & 24 & CCMP 115 & 8.71 & $>150$ \\
\hline 13 & 2.686 & 24 & CCMP 115 & 8.71 & $>150$ \\
\hline 14 & 1.825 & 48 & CCMP 115 & 6.99 & $>150$ \\
\hline 15 & 3.292 & 48 & CCMP 115 & 6.99 & $>150$ \\
\hline 16 & 3.691 & 48 & GONY 7 & 7.16 & $>150$ \\
\hline 17 & 2.938 & 48 & MOG 835 & 3.75 & $>150$ \\
\hline 18 & 3.691 & 48 & MOG 835 & 3.75 & $>150$ \\
\hline
\end{tabular}

GONY 7, mean R was less for the experimental group: 3.733 vs. $8.567 \mathrm{~L} \cdot \mathrm{h}^{-1}$ for the predicted value, student $t=-13.888, \mathrm{df}=2$ and the difference was significant at $P<0.01$.

\section{DISCUSSION}

Before comparing our results with those of Bougrier et al. [5] and Lassus et al. [12], we must point out some 
Table VII. Experiment 3C: Initial feeding responses of Crassostrea gigas acclimated to Isochrysis $\mathrm{sp}$. Environmental conditions, temperature $=15.2$ $\pm 0.05{ }^{\circ} \mathrm{C}$ and $\mathrm{U}=15.3 \pm 0.62 \mathrm{~cm} \cdot \mathrm{s}^{-1}$. Cell densities chosen were equal in dry weight.

\begin{tabular}{|c|c|c|c|c|c|c|c|}
\hline \multicolumn{2}{|c|}{ Oyster } & \multicolumn{3}{|c|}{ Mixed culture } & \multirow{2}{*}{$\begin{array}{l}\text { Time delay } \\
\text { (min) }\end{array}$} & \multicolumn{2}{|c|}{$\mathrm{R} L \cdot \mathrm{h}^{-1}$ oyster } \\
\hline$\#$ & $\begin{array}{l}\text { Dry wt. } \\
\text { (g) }\end{array}$ & $\begin{array}{c}\text { Isochrysis sp. } \\
\times 10^{6}\end{array}$ & $\begin{array}{l}\text { Alexandri } \\
\quad \text { strain } \times\end{array}$ & $0^{3}$ & & Observed & Predicted \\
\hline 1 & 2.842 & 1.17 & CCMP 11 & 12.3 & $0(68)$ & 10.9 & 7.3 \\
\hline 2 & 2.176 & 1.40 & CCMP 11 & 12.3 & $>140$ & 0.0 & 6.5 \\
\hline 3 & 0.974 & 1.40 & CСMP 11 & 12.3 & $27(45)$ & 6.4 & 4.6 \\
\hline 4 & 2.269 & 0.86 & CCMP II & 11.3 & $25(30)$ & 7.9 & 6.6 \\
\hline 5 & 2.513 & 2.17 & GONY 7 & 8.3 & $>150$ & 0.0 & 6.9 \\
\hline 6 & 3.298 & 2.17 & GONY 7 & 8.3 & $10(>135)$ & 3.6 & 7.8 \\
\hline 7 & 3.542 & 2.32 & GONY 7 & 7.0 & $0(32)$ & 3.2 & 8.1 \\
\hline 8 & 5.531 & 2.32 & GONY 7 & 7.0 & $3(65)$ & 4.4 & 9.8 \\
\hline
\end{tabular}

differences in the way that the feeding bioassays were set up. The most notable is that the importation of $C$. gigas from the west to the east coast of Canada involved air travel on ice resulting in temperature shocks on acclimation to local seawater temperatures. In addition, Lassus et al. [12] used juvenile oysters of a uniform, small size in comparison with Bougrier et al. [5] and in the present study where a wider range of sizes was employed. Another difference was the reference or control diet offered. Thus, only Bougrier et al. [5] used a mixed microalgal diet consisting of Isochrysis sp. strain T-ISO and Chaeto-ceros calcitrans, while Lassus et al. [12] used a reference diet consisting only of non-toxic Alexandrium tamarense. Finally, in the study of Bougrier et al. [5], clearance rates were determined only during active periods of oyster feeding (known inactive periods were discarded). Because in the present study we were able to determine in real time when oysters were, or were not, feeding, we have calculated $\mathrm{R}$ on the basis of the total time actually exposed in particular feeding experiments.

The juvenile oysters used by Lassus et al. [12] with a mean dry weight of $0.83 \mathrm{~g}$ would be predicted by the Bougrier et al. [5] model to have $\mathrm{R}=3.87$ at $12{ }^{\circ} \mathrm{C}$ and $\mathrm{R}=4.12 \mathrm{~L} \cdot \mathrm{h}^{-1}$ at $16^{\circ} \mathrm{C}$ if fed an acceptable microalgal reference diet. The observed mean $R$ values of Lassus et al. [12] are, in fact, only 8 and $3 \%$ of the predicted reference values. We consider that such low rapid start/ stop uptake rates would be below the sensitivity level of the flow fluorometer method we employed to measure R. Thus, a zero recorded by us for Alexandrium sp. may simply mean an $\mathrm{R}<10 \%$ of the reference diet rate. These considerations explain the apparent contradiction with the results obtained by Lassus et al. [12] that acclimation to $A$. tamarense increased $R$, contrary to the present results.

Our reference results give values of $R$ similar to the empirical model derived by Bougrier et al. [5], despite the differences in pre-feeding history noted. This is evidence that both populations of oysters are maximally filtering in good conditions for feeding. Our results also show that of all the control results in which oysters were fed a reference diet, a significant proportion, 6 out of 22 or $27 \%\left(\chi^{2}=37.64\right.$, df $\left.1, P<0.01\right)$, of oysters never began feeding during our experiments.
Thus, a reluctance of some oysters to feed is a characteristic of this bioassay and may reflect prior treatment (e.g. temperature shock) and feeding history, or unexplained factors intrinsic to the oyster.

Because only $73 \%$ of oysters initiated feeding during our control experiments, we compared oyster feeding/not feeding using this experimentally observed proportion. Significantly fewer oysters initiated feeding when offered $A$. tamarense strain CCMP 115 $\left(\chi^{2}=72.61\right.$, df $\left.1, P<0.01\right)$ than when offered Isochrysis sp. Both of the other toxic strains of Alexandrium offered as food failed to initiate feeding in oysters (tables $V, V I$ ). Our results consistently show that oysters prefer Isochrysis sp. to Alexandrium sp. An attempt to acclimate oysters to non-toxic $A$. tamarense for periods up to $48 \mathrm{~h}$ was unsuccessful. It is possible that a longer time is required for acclimation since Dupuy and Sparks [7] mention a 2 week lag in the uptake by Pacific oysters of Alexandrium catenella. The possibility that oysters acclimated to unialgal Isochrysis $\mathrm{sp}$. would feed on a mixed culture consisting of this species and Alexandrium sp. was confirmed in experiment 3C (table VII). The presence of non-toxic or toxic Alexandrium sp. caused start/stop feeding, a pattern absent in all our oyster bioassays with Isochrysis $\mathrm{sp}$. as the sole food source.

The recognition of start/stop feeding caused by exposure to Alexandrium sp., either in pure or mixed cultures, has implications for further bivalve feeding studies. It suggests a mechanism that explains how reduced clearance rates in the presence of Alexandrium sp. cells can occur. The on/off mechanism is consistent with Jørgensen's [9] view that the filter pump is adapted to continuously process seawater and exploit characteristic, location-specific seston loads for growth. Under sub-optimal environmental conditions, Jørgensen [9] considers that the pump shuts off by valve gap reduction, mantle edge and siphon retraction, resulting in no or reduced pumping and, therefore, filtration rate. Our results with toxic and non-toxic Alexandrium sp. at typical bloom concentrations in the Bay of Fundy suggest that it causes a similar response in oysters. The presence of Alexandrium in seawater cannot be described as a sub-optimal environmental condition, and we suggest that it supports the physiological 
response proposed in Wildish and Saulnier [21] stimulated by chemical cues from the Alexandrium sp. and results in mantle closing/opening, causing the filter pump to switch off/on. As demonstrated in this work by flow fluorometer monitoring, the response does not involve reduction in the filtration rate, but episodes when the filter pump is either on or off.

We do not consider that PSP toxins are directly involved in inhibiting the initial feeding responses of oysters when exposed to Alexandrium $\mathrm{sp}$. cells because both toxic and non-toxic strains cause start/stop feeding. Blanco and Campos [4] have described the release of soluble exocrines by toxic and non-toxic A. tamarense capable of inhibiting the growth of other microalgae, including a unialgal culture of Isochrysis galbana. Ward et al. [19] showed that increased clear- ance rates in the scallop, Placopecten magellanicus, were caused by water-soluble exocrines present in diatom culture water. Further examples where the exocrines may act as a depressant for bivalve feeding are reviewed by Targett and Ward [18]. Thus, it is possible that exocrines produced by Alexandrium sp. could act as a trigger for feeding inhibition in the Pacific oyster.

Despite these initial feeding responses to Alexandrium sp., post-ingestive responses (e.g. absorption) in the oyster seem to be normal [12]. This suggests that once Alexandrium sp. are consumed, the paralytic shellfish poisoning toxins become physiologically available to the oyster and may result in further behavioral responses, which have not been investigated here.

\section{REFERENCES}

[1] Anderson D.M., Kulis D.M., Doucette G.J., Gallagher J.C., Balech E., Biogeography of toxic dinoflagellates in the genus Alexandrium from the northeastern United States and Canada, Mar Biol 120 (1994) 467-478.

[2] Bardouil M., Bohec M., Cormerais M., Bougrier S., Lassus P., Experimental study of the effects of a toxic microalgal diet on feeding of the oyster Crassostrea gigas Thunberg, J. Shellfish Res. 12 (1993) 417-422.

[3] Bardouil M., Bohec M., Bougrier S., Lassus P., Truquet P., Feeding responses of Crassostrea gigas (Thunberg) to inclusion of different proportions of toxic dinoflagellates in their diet, Oceanol. Acta 19 (1996) 177-182.

[4] Blanco J., Campos M.J., The effect of water conditioned by a PSP-producing dinoflagellate on the growth of four algal species used as food for invertebrates, Aquaculture 68 (1988) 289-298

[5] Bougrier S., Geairon P., Deslous-Paoli J.M., Bacher C., Jonquières $G$., Allometric relationships and effects of temperature on clearance and consumption rates of Crassostrea gigas (Thunberg), Aquaculture 134 (1995) 143-154.

[6] Bricelj V.M., Lee J.H., Cembella A.D., Anderson D.M., Uptake kinetics of paralytic shellfish toxins from the dinoflagellate Alexandrium fundyense in the mussel Mytilus edulis, Mar. Ecol. Prog. Ser. 63 (1990) 177-188.

[7] Dupuy J.L., Sparks A.K., Gonyaulax washingtonensis, its relationship to Mytilus californianus and Crassostrea gigas as a source of paralytic shellfish toxin in Sequin Bay, Washington, Proc. Nat. Shellfish Assoc. 58 (1968) 2.

[8] Guillard R.R.L., Ryther J.H., Studies on marine planktonic diatoms. I. Cyclotella nana Hustedt and Detonula confervacea (Cleve) Gran, Can. J. Microbiol. 8 (1962) 229-239.

[9] Jørgensen C.B, Bivalve filter fecding revisited, Mar. Ecol. Prog. Ser. 142 (1996) 287-302.

[10] Kao C.Y., Paralytic shellfish poisoning, in: Algal toxins in seafood and drinking water. Falconer I. (ed.), Academic Press, San Diego, CA, 1993, pp. 75-86.
[11] Lassus P., Fremy J.M., Ledoux M., Bardouil M., Bohec M., Patterns of experimental contamination by Protogonyaulax tamarensis in some French commercial shellfish, Toxicon 27 (1989) 1313-1321.

[12] Lassus P., Wildish D.J., Bardouil M., Martin J.L., Bohec M., Bougrier S., Ecophysiological study of toxic Alexandrium spp. effects on the oyster Crassosira gigas, in: Harmful and toxic algal blooms. T. Yasumoto, Oshima Y., Fukuyo Y. (eds.), IOC/UNESCO, 1996, pp. 409-412.

[13] Lesser M.P., Shumway S., Effects of toxic dinoflagellates on clearance rates and survival in juvenile bivalve molluscs, J. Shellfish Res. 12 (1993) 377-381.

[14] Russell F.F., Marine toxins and venomous and poisonous marine plants and animals (invertebrates), Adv. Mar. Biol. 21 (1984) 59-217.

[15] Shumway S.E., Toxic algae, World Aquac. 20 (1989) 65-74.

[16] Shumway S.E., Cucci T.L., The effects of the toxic dinoflagellate Protogonyaulax tamarensis on the feeding behaviour of bivalve molluscs, Aquat. Toxicol. 10 (1987) 9-27.

[17] Sullivan J.J., Wekell M.M. The application of high performance liquid chromotography in a paralytic shellfish poisoning monitoring program, in: Seafood quality determination. Proc. Int. Symp. on seafood quality determination. Kramer D.E., Liston J. (eds.), Elsevier, 1987, pp. 357-372.

[18] Targett N.M., Ward J.E., Bioactive microalgal metabolites: mediation of subtle ecological interactions in phytophagous suspension-feeding marine invertebrates, Bioorg. Mar. Chem. 4 (1991) 91-118.

[19] Ward J.E., Cassel H.K., MacDonald B.A., Chemoreception in the sea scallop Placopecten magellanicus (Gmelin). I. Stimulatory effects of phytoplankton metabolites on clearance and ingestion rates, J. Exp. Mar. Biol. Ecol. 163 (1992) 235-250.

[20] Wildish, D.J., Kristmanson D.D., enthic suspension feeders and flow. Cambridge University Press, New York, 1997, 409 p.

[21] Wildish, D.J., Saulnier A.M., Hydrodynamic control of filtration in Placopecten magellanicus, J. Exp. Mar. Biol. Ecol. 174 (1993) 65-82. 